Z. klin. Chem. u. klin. Biochem.

7. Jg., S. $350-351$, Juli 1969

\title{
The Activity of the Urinary Lactate Dehydrogenase Isoenzymes in Acute Glomerulonephritis in Childhood
}

\author{
By I. Marosvári and B. GoLdschmidt
}

From the Department of Pediatrics No II, Universtiy Medical School Budapest, Hungary

(Eingegangen am 10. Februar 1969)

A considerable increase in LDH activity was demonstrated in the urine of children suffering from acute glomerulonephritis. The LDH isoenzyme distribution was also found to be different, compared to the normal. During recovery from the disease the pathologic $\mathrm{LDH}$ values returned gradually to normal. Owing to the similarity of the isoenzyme patterns, the study of the urinary. LDH and its isoenzymes offers no possibility of distinguishing proteinuria due to renal disease from "functional" proteinurias.

Im Harn an akuter Glomerulonephritis leidender Kinder war eine bedeutende Steigerung der LDH-Aktivität ${ }^{1}$ ) nachweisbar. Im Vergleich zu normalem Harn war auch die LDH-Isoenzym-Verteilung abweichend. Während des Krankheitsverlaufes normalisierten sich die pathologischen LDH-Werte stufenweise. Aber infolge der Åhnlichkeit der Isoenzym-Bilder bietet die Untersuchung der LDH und der LDH-Isoenzyme im Harn keine Möglichkeit zur Differenzierung der durch die Nierenkrankheit bedingten und der „funktionellen“ Proteinurien.

Lactate Dehydrogenase (LDH) activity in the urine was demonstrated for the first time in 1958 (1). In 1959 RosAlKIE and WILKINSON (2) found LDH activity to be increased in the urine in various diseases of the kidneys. In 1964 WACKER-DorfmaN and AMADOR (3) found that $\mathrm{LDH}$ activity in the urine was elevated in the active phase of three adult cases of glomerulonephritis, while activity became normal in cured cases. Considering the fact that no data are available on the behaviour of urinary $\mathrm{LDH}$ for a larger series of children suffering from acute glomerulonephritis and that at this age the isoenzyme composition of normal urine $\mathrm{LDH}$ is not well known, we carried out the present studies.

\section{Methods}

The activity of the isoenzymes and the total amount of urinary $\mathrm{LDH}$ was measured with a colorimetric method elaborated originally for sera $(4,5)$. Separation of the $\mathrm{LDH}$ isoenzymes was carried out with the heat-inactivation method (6). Using the latter method, it is possible to distinguish three types of $\mathrm{LDH}$ isoenzyme fraction: the thermostable isoenzyme $\mathrm{LDH}_{1}$, the indifferent isoenzymes $\mathrm{LDH}_{2-4}$ and the thermolabile $\mathrm{LDH}_{5}$ isoenzyme. According to Wüst (6) the serum can be split into these three isoenzyme fractions.

Our work shows that not only the serum but also the urinary $\mathrm{LDH}$ can be divided into three fractions by using the above method. "Human-Albumin" was not used to supplement the urinary protein concentrations. The enzyme determinations were made from urine collected for 12 or 24 hours in coolers. LDH activity is expressed in Wroblewski Units(E) ${ }^{2}$ ) for urine excreted during 8 hours. We determined the urine and serum total LDH activity, as well as the activities of their isoenzymes, in the course of the disease beginning from the first week of the disease up to the fifth week in 15 children ( 7 boys and 8 girls) suffering from acute glomerulonephritis. The urine and serum of 15 healthy children aged 6 to 12 years, were analysed as controls.

\section{Results}

The total LDH and the isoenzyme activities of the urine and serum of 15 healthy controls are shown in the

1) $\mathrm{LDH}=\mathrm{L}-\mathrm{L}$ actate: NAD oxidoreductase (EC 1.1.1.27).

2) $\mathrm{E}=$ Wroblenski-Unit; one Wroblewski-Unit $=0,48$ international Units.
Table 1. Total LDH activity in the urine is $1940 \mathrm{E} / 8$ hours. It appears that 100 per cent of the activity is found in the thermolabile fraction. The average value of total LDH activity of the serum is $350 \mathrm{E} / \mathrm{ml}$. In case of the serum only 25 per cent of the total LDH activity is found in the thermolabile isoenzyme fraction. Considerable activity is also found in the indifferent and thermostable fractions. In our cases of acute glomerulonephritis (Fig. 1) it was possible to demostrate a significant increase in total urinary $\mathrm{LDH}$.

The isoenzyme distribution of the total urinary $\mathrm{LDH}$ activity was also changed significantly. The thermolabile fraction, also present in normal urine, remained practically unchanged. Most of the increased urinary

Tab. 1

LDH activities of 15 healthy controls. $E=$ Wroblewṡki-unit

\begin{tabular}{ccccc}
\hline LDH & $\begin{array}{c}\text { Total } \\
\text { activity }\end{array}$ & $\begin{array}{c}\text { thermo- } \\
\text { stable }\end{array}$ & $\begin{array}{c}\text { thermo- } \\
\text { labile }\end{array}$ & $\begin{array}{c}\text { indif- } \\
\text { ferent }\end{array}$ \\
\hline Urine & $\begin{array}{c}1940 \pm 960 \\
\mathrm{E} / 8 \mathrm{~h}\end{array}$ & - & $100 \%$ & - \\
Serum & $\begin{array}{c}350 \pm 150 \\
\mathrm{E} / \mathrm{ml}\end{array}$ & $30 \%$ & $25 \%$ & $45 \%$ \\
\hline
\end{tabular}
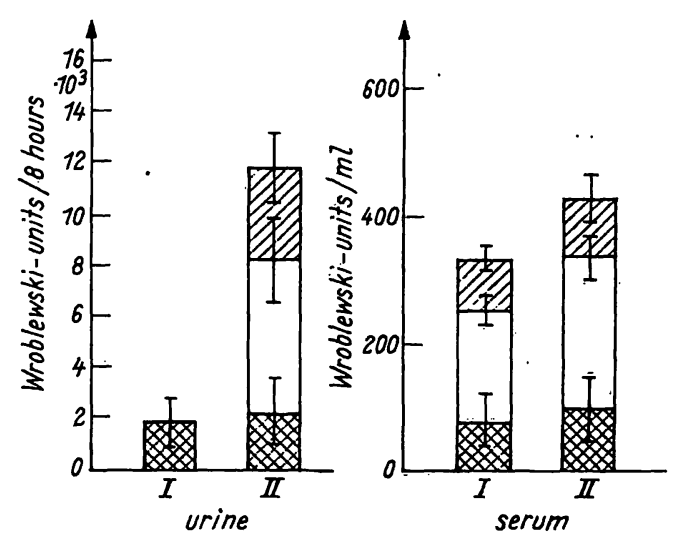

Fig. 1 Activities of total $\mathrm{LDH}$ and $\mathrm{LDH}$ isoenzyme fractions in urine and
serum of healthy children (I) and children with acute nephritis (1 serum of healthy children (I) and childre $\square=$ indifferent LDH
W/// $=$ thermostable LDH 


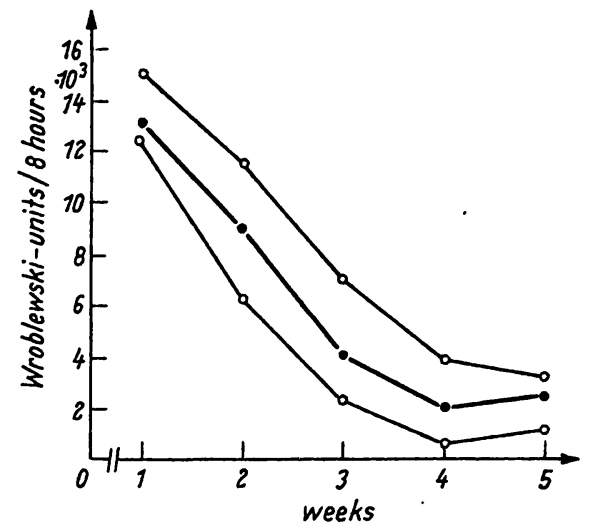

a

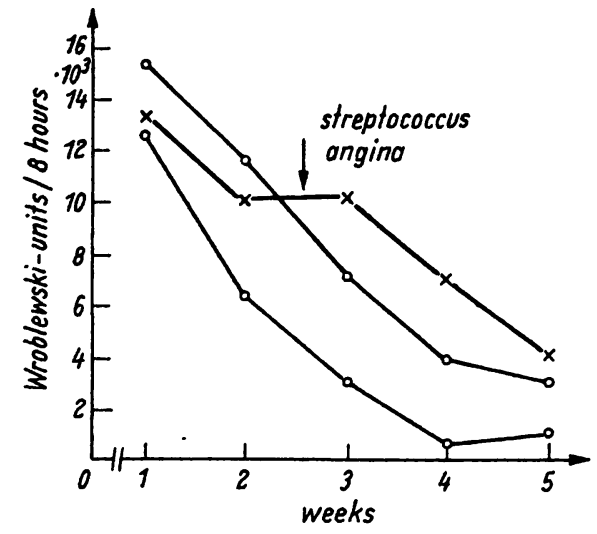

b
Fig. 2

Course of urinary LDH activities

a) in the case of an uncomplicated course of the disease $(n=12)$

$\leadsto=$ extreme valus, $\bullet-\infty=$ average

b) in the case of intercurrent streptococcal angina, compared with uncomplicated course (see fig. 2a)

$\multimap=$ extreme values from fig. 2a), $x-x=$ average of patient with angina
$\mathrm{LDH}$ activity, 52 per cent on the average, was found in the indifferent isoenzyme fraction, while 22 per cent were found in the thermostable fraction.

In the serum of our patients, LDH activity was found to reach the upper limit of the normal ( $492 \pm 80 \mathrm{E} / \mathrm{m} /)$. With regard to isoenzyme distribution, a moderate rise of the indifferent isoenzyme fraction was observed $(300 \pm 64 \mathrm{E} / \mathrm{m} /)$. For a comparison of the serum and urinary $\mathrm{LDH}$ isoenzyme compositions, the value relating to the sera are magnified 25 times in the figure.

In the case of an uncomplicated course of the disease (Fig. 2a) the initially increased urinary $\mathrm{LDH}$ values decreased gradually, and usually reached the normal values by the fourth week of the disease. At this time the urinary sediment usually is still pathologic, and microhaematuria can be observed.

In one of our patients intercurrent Streptococcal angina caused a relapse. The urinary sediment got worse and a repeated decrease of the serum complement as well as an increase in the urinary $\mathrm{LDH}$ activity was observed in the third week of the disease (Fig. 2b).

\section{Discussion}

There is a divergence of opinions concerning the origin of urinary LDH in normal urine. CROKson and coworkers (9) think it likely that the enzyme is of seral origin. Plummer and coworkers (10) suggest a renal origin. Other sources of the excreted urinary $\mathrm{LDH}$ must be considered in pathologic conditions. A considerable increase in urinary $\mathrm{LDH}$ activity was demonstrated in case of malignant tumours of the urinary tract (7), or with benign tumourous affections (8) and in chronic pyelonephritis (3). Dubach (8) believes that the causitive factor of the increase in urinary $\mathrm{LDH}$ activity is the increased number of cellular elements, mainly white blood cells and red blood cells, and the urine enzyme release taking place from these cells. The white blood cells contain the particularly thermolabile isoenzyme $\left(\mathrm{LDH}_{5}\right)$ whilst the red blood cells mainly the thermostable one $\left(\mathrm{LDH}_{1}\right)$.

In acute glomerulonephritis the role of the white blood cells in producing the increase of urinary $\mathrm{LDH}$ is probably not very important, since we have found that the thermolabile isoenzyme fraction shows no essential difference if compared to the normal. On the other hand urinary $\mathrm{LDH}$ activity remains considerably elevated even at the time when the urinary sediment contains few white blood cells. The causitive role of the red blood cells may be considered, but LDH liberated from these cells must be taken into account only in case of haemolysis above $0,5 \mathrm{~g} / 100 \mathrm{ml}$ (2). Haemolysis of this degree was not found after the 3rd-4th days of the disease. Moreover in the recovery phase of acute glomerulonephritis when residual haematuria is still present, the urinary $\mathrm{LDH}$ activity is already completely normal. Thus the increase in urinary $\mathrm{LDH}$, caused by haemolysis taking place in the urine, cannot be responsible for the results obtained. The urinary LDH isoenzyme pattern observed by us in acute glomerulonephritis can be explained by the loss of enzymes from the serum or the renal parenchyma, because the isoenzyme composition of these is qualitatively highly similar. In connection with this question our findings in postural proteinuria are remarkable, where under load the urinary protein electrophoretic patterns show great similarity to sera, and isoenzyme compositions were similar to the findings in acute glomerulonephritis (11). In this way urine analysis for urinary $\mathrm{LDH}$ seems to be unsuitable for distinguishing proteinuria due to renal lesion from "functional" proteinuria.

\section{References}

1. Amelung, D., H. D. Horn and E. Schröder, Klin. Wschr. 36, 963 (1958). - 2. Rosalkie, S. B. and J. H. Wilkinson, Lancet London 1959/II, 327. - 3. WACKER, W. E. C., L. E. DorpMAN and E. Amador, J. Amer: Med. Ass. 188, 671 (1964). - 4. Sigma Technical Bulletin No 500 (1965). - 5. Cabaud, P. G. and F. Wroblewski, Amer J. Clin. Path. 30, 234 (1958). - 6. Wüst, H., E. Arnold and H. SchöN, Klin. Wschr. 43, 500 (1965). - 7.
WÁcker, W. E. C. and L. E. Dorfaran, J. Amer. Med. Ass. 181 972 (1962). - 8. Dubsch, U. C., Helv. med. Acta 33, 139 (1966). 9. Crockson, R. A., Lancet London 1961/I, 140. - 10. Plummer, D. T. and F. D. LeAtHwood, Biochem. J. 103, 172 (1967). - 11. Marosvíri, I. and B. GoldschMidt, Klin. Lab. Szakcsoport, Szombathely (1967).
Dr. I. Marosvari Tüzoltó u. 7-9 Budapest IX, Hungary 